\title{
Libraries with a Future: How Are Academic Library Usage and Green Demands Changing Building Designs?
}

\section{Michael Wescott Loder}

\begin{abstract}
Support for the modular system of building construction, touted in the second half of the 20th century as the best basis for academic library building design, appears to be waning. A study of "green" libraries in 2008 revealed that not only has energy conservation become important, but that spaces designed for users rather than books have become paramount. The modular system worked particularly well for housing ever-expanding book collections, but collection growth is no longer a practical goal. Users want and need a greater variety of spaces, which purpose-built rooms are better at meeting.
\end{abstract}

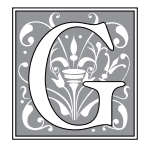

reenness and LEED (Leadership in Energy and Environmental Design $)^{1}$ have become hot features for many new buildings since the turn of the century. While increasing numbers of public libraries have achieved LEED ratings for their energy and sustainable design features, fewer college and university libraries can yet boast of this designation. In 2008, the author visited a range of these green academic libraries in an attempt to see how their design approaches were affecting structure and usage. LEED's criteria involve more than just using less electricity or recycling construction materials. They also grant points for effective space functions and a building's long-term operational outlook. Touring these buildings, observing, and speaking with local staff, the author found himself reflecting on the contrast between what he was hearing concerning the functions of these new spaces and the "modern" design criteria that academic library design experts promoted throughout much of the second half of the 20th century. To understand that contrast and where these buildings are now headed, a historical understanding of the older criteria is essential.

\section{Background}

The July 1984 issue of College $\mathcal{E}$ Research Libraries featured an article ${ }^{2}$ by David Kaser in which he provided a nearly comprehensive overview of academic library building construction over the previous twenty-five years. An open and vocal advocate of the modular system of library design, Kaser bemoaned the growing shift away from the purely boxes-withina-box simplicity of such designs and the increasing use of special function spaces. 
This article was but a prelude to his more comprehensive history of academic libraries entitled The Evolution of the Academic Library Building published by Scarecrow in $1997 .{ }^{3}$ Yet, even in this later work, Kaser showed little interest in moving away from his earlier position, as he continued to promote modular systems and condemn fixed function spaces. Modular designs were the standard.

A "modular" library, as its name implies, is a building in which floor layouts form a uniform grid, often marked by support pillars set at regular intervals. It would be expected that every square or rectangle of space defined by these columns would be exactly the same size. It would also be expected that each floor of a modular library would be a duplicate of any floor above or below it. Often, the size of a module reflected the dimensions of standard book shelving units. Using modules as a basis for a building gave libraries an almost unlimited ability to move stacks, furniture, and user spaces to compensate for ever-growing collections - then the focus of concern.

The late Ralph Ellsworth and Keyes D. Metcalf, through the force of their personalities, their numerous writings, and their prominent positions within the academic libraries community, had been firm advocates of modular systems. Metcalf's Planning Academic and Research Library Buildings ${ }^{4}$ was for many years the bible for any academic librarian contemplating a building project, and it continues to live on under the same title and philosophy in a third edition authored by Philip D. Leighton and David C. Weber (ALA 1999). Metcalf worked closely with the Bostonbased architectural firm of Shepley, Bulfinch, Richardson \& Abbott. Considering that firm's continuing prominence in the world of academic library projects in this country, ${ }^{5}$ the importance and pervasiveness of the modular system in the late 20th century cannot be ignored.

The 1990s saw a surge in academic library construction as colleges and universities struggled to accommodate a rapid expansion in academic publishingparticularly in journals - and increasingly diverse functions while also using these often giant and visual structures to raise their own prestige. ${ }^{6}$ The author's own home library was part of this growth as it moved from inadequate and confining quarters into a stand-alone building three times as large and offering all the latest in technology. While many of these structures continued the established modular tradition, others chose to embrace postmodernism, using more complex designs with more symbolism. But by the mid-'00s, the growing worldwide energy crisis was affecting even this approach, and energy savings became more important. An awareness of this change led the author to take a closer look at a range of buildings beyond those readily reachable within his own Middle Atlantic region.

Is the modular system gone? Have enough changes occurred to the fundamental mission of academic libraries and their buildings that a new standard is called for? The libraries the author visited are different and indicative of the major changes that are occurring, and not just because of greenness. The enormous changes in technology resulting from the expansion of computing into all aspects of library activities and librarianship have irrevocably remolded what librarians do. Newer librarians today are bringing to the profession different skills, knowledge, and, most important, a different world view from even what was taught and promoted as recently as 15 years ago. Now it is starting to change the buildings most of us work in, the "library" of librarianship. Library work has changed quickly and considerably, but buildings more slowly. In many cases, cosmetic alterations have occurred; but, if the libraries the author visited are any indication, the "Library with a Future" will involve more than simply a matter of adding ethernet to every room or placing workstations in every cubicle. Academic libraries are becoming physical and electronic intellectual gathering places rather than 
repositories of books. They are a place of choice for students and faculty wanting to get academic work done. With that focus in mind, new and renovated buildings are evolving into different structures that will meet the greater academic and energy needs of this century.

\section{The Visits}

In the spring and summer of 2008, the author visited a total of ten new, or newly renovated, academic libraries across the United States. All but two had received or had applied for a LEED rating, testifying to their new "greenness."

But what he found most striking about these "green" libraries was not their energy efficiency or their healthy interiors. Rather, it was their close attention to changing user needs and desires - an approach practical and efficient in itself. While most of these libraries had waterless urinals, non-off-gassing carpeting and other symbols of a low-energy, sustainable environment, it was the focus on spaces for patrons rather than for collections that was most noticeable. Naturally lit, comfortable areas, study rooms, wireless capacity, snack bars, and more electrical outlets were evident everywhere.

At the start of this project in 2007, there was still little information available about which new academic libraries were LEED-certified or had "green" aspects. Informal queries indicated a lot of interest but identified little definite information and even fewer completed projects. By

\section{TABLE 1}

\section{List of Libraries Visited (in order of visitation):}

Duke University, Durham, N.C.:

- Perkins Complex: Completed 1928, 1948, 1968. Renovation of 1968 addition under way when visited, completed spring 2009. LEED not yet completed.

- Bostock Library: Opened 2005. LEED certification submitted, never completed.

Emory University, Atlanta, Ga.:

- Asa Griggs Candler Library: opened in 1926. Renovation opened in 2003. LEED Silver.

Georgia State University, Atlanta, Ga.:

- University Library. Built 1966. Renovation completed February 2007. Non-LEED. Some green features.

University of Florida, Gainesville, Fla.:

- George A. Smathers Libraries, Library West. Originally built in 1967. Following renovation, reopened in August 2006. LEED Gold.

University of Colorado, Boulder, Colo.:

- William A. Wise Law Library. Occupied August 2006. LEED Gold.

University of Califronia, Merced, Calif::

- Library. Occupied in 2005, completed 2006, but still changing as of 2008. LEED Gold.

Pacific University, Forest Grove, Ore.:

- $\quad$ Library. Occupied August 2005. LEED Certified.

Pennsylvania State University, University Park, Penn.:

- School of Architecture and Landscape Architecture Library. Occupied in summer 2005. LEED Gold.

Penn State/Wilkes Barre, Lehman, Penn.:

- Nesbitt Library. Completed 2008. LEED Certified.

Massachusetts Institute of Technology, Cambridge, Mass.:

- Hayden Library (Building 14). Completed 1950. Photovoltaic panels on roof. Installed September 2004. 


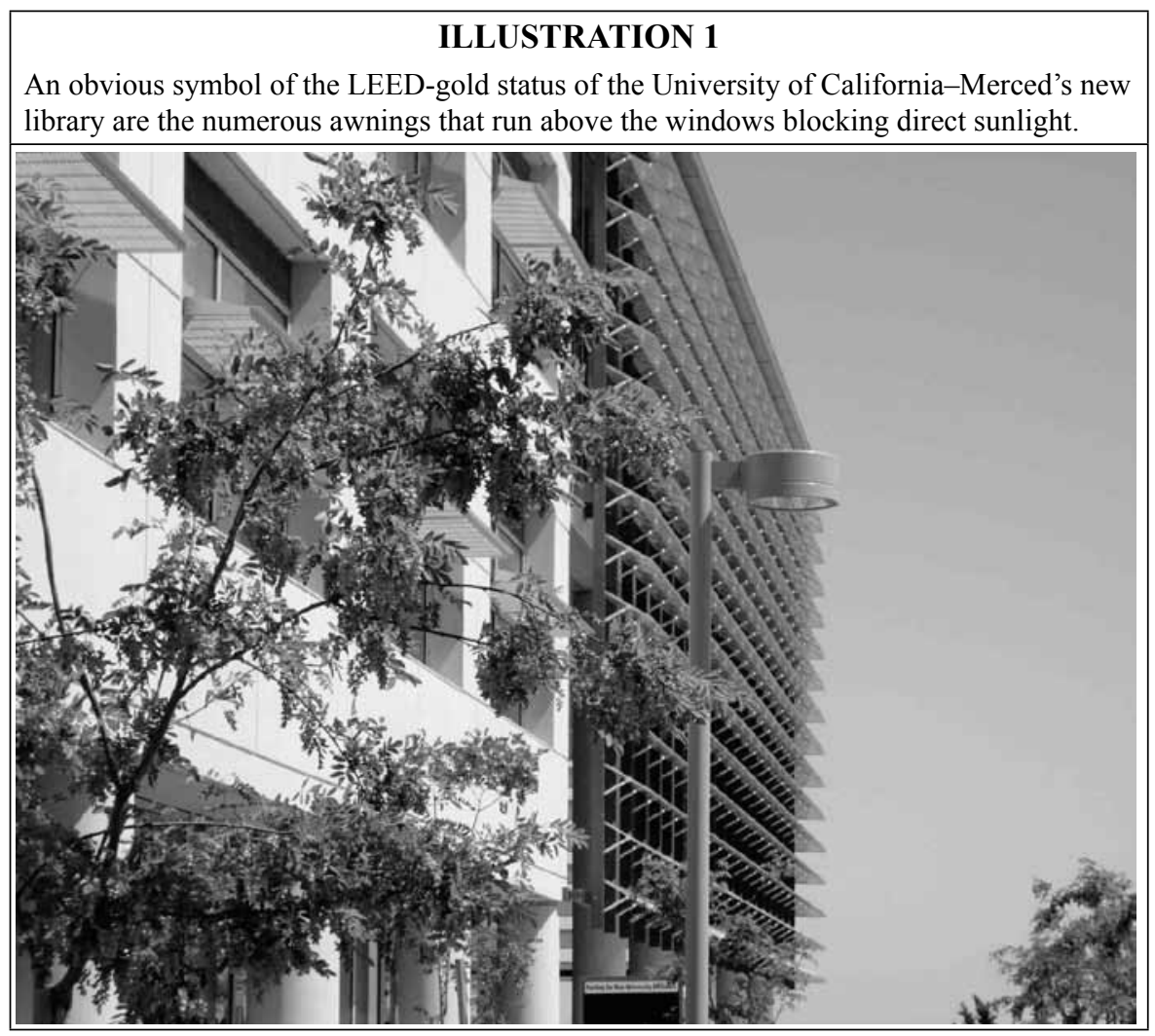

networking with colleagues within LLAMA's Buildings and Equipment Section (BES), searching the Web and reviewing the annual architectural issues of Library Journal and American Libraries, a list grew to include 11 locations. Not all of these were actually LEED-certified. Some just had "green elements." Others had applied for LEED certification but it had not yet been granted. Still, it was a start. Four road trips in 2008 allowed visits to those libraries noted in table 1 including libraries in the south, west, and New England.

At each location, a tour of entire buildings was followed by meetings with library personnel, much note taking and picture taking. For those libraries where there were personal connections prior to the visit, the receptions were warm and helpful. Often the hosts went out of their way to answer questions and show off every aspect of their facilities. Even in those locations where spur-of- the-moment visits took place, personnel were friendly and tried to accommodate. Set questions concerning LEED factors helped give a common perspective, but often the buildings spoke for themselves via their layouts, furnishings, and special features.

\section{General Comments}

In every location, the author found that growth is now an end game with an ultimate collection size already determined. In libraries going through renovations, such as at Duke and Emory, collections were being shifted, compacted, and moved aside to provide more and more user space. In new buildings, such as UC-Merced, Pacific, and the Penn State locations, user space had priority from the beginning. As a result, the modular design system is increasingly taking a back seat to designs that provide for more user appeal. 
In virtually every case, the decision to go LEED started at the top, outside the library. In many cases, financial managers or presidents were the officers who saw LEED as both a way to save money in the long run and add prestige to an institution's new constructions. Library directors were generally supportive of LEED, even if it was not their idea initially.

The buildings themselves varied considerably, but a few common threads emerged:

- Climatically unprotected glass walls are out, but windows and natural "day lighting" were everywhere. As a result, LEED libraries felt warmer and friendlier, whether modern or more traditional in style.

- LEED libraries tended to be more sensitive to the geography of space, with their designs appropriate to the local climate instead of a one-design-fits-all approach. This was particularly noticeable in the UCMerced and Pacific University designs.
- Book collections are no longer front and center. It was often hard to find the books initially. Stacks are more concentrated. Compact shelving is standard even in public, browsing collections. Virtually every library visited-new or renovated-had at least some compact shelving in place or plans to put it in.

- The technical functions of cataloging, processing, and catalog maintenance are a minor and declining part of a library's functions. Technical staffs are smaller and their spaces increasingly marginalized. In several cases, technical services had been moved, or will soon move, out of the library entirely.

- Grand entrance stairs are the new "Big Thing." In the University of Florida, UC-Merced, and the Wise Law building, a visitor has to either climb a stair or take an elevator to get into the library proper or even to find a circulation desk. Facing a stair as the first thing one must do on entering a building was a bit disconcert-

\section{ILLUSTRATION 2}

Carefully preserved trees provide summer shade for the tall windows that, in turn, admit lots of light on winter days in Pacific University's new LEED-certified library in Forest Grove, Oregon. Despite a gloomy day, the interior of this library felt warm, bright, and welcoming.

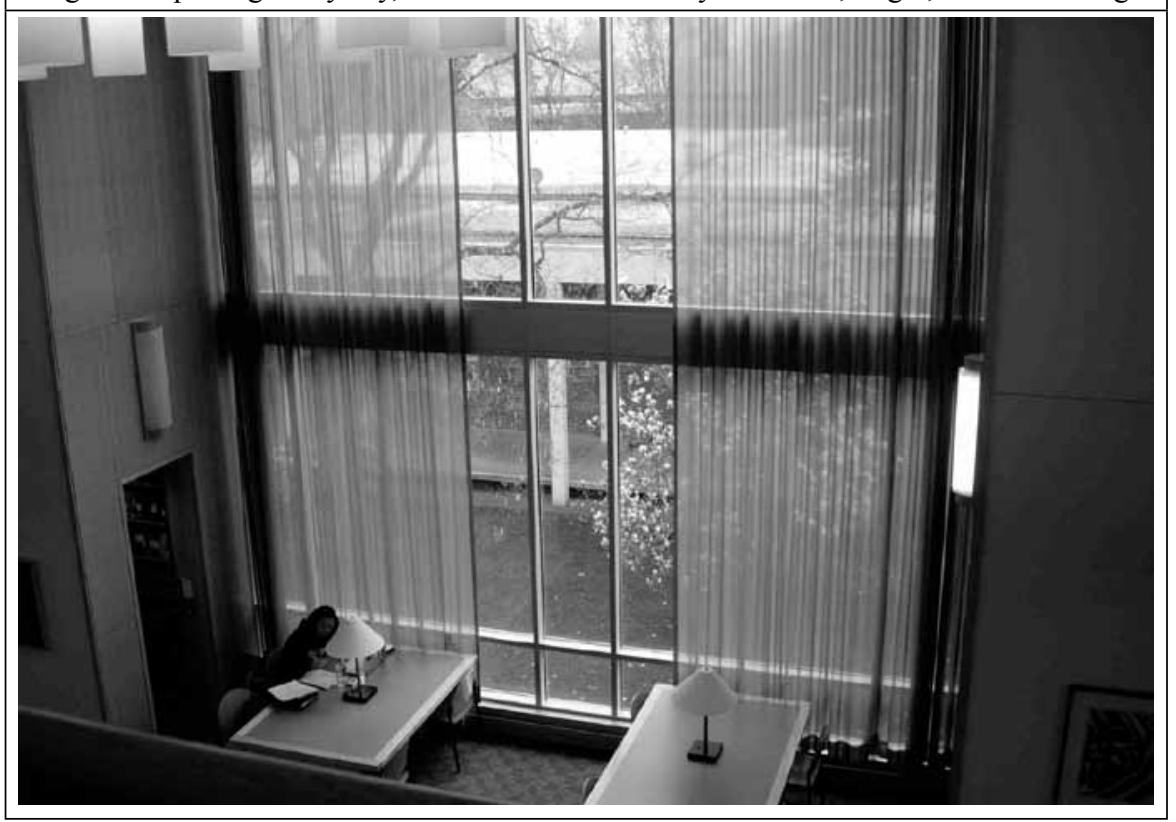


ing, but that was the way these buildings function.

- But the most noticeable overall characteristic of all these libraries were their attention to enhanced personal patron comfort, including lots of varied seating, softer natural light, wide tables near windows, and user-controlled task lighting.

\section{Discussion}

Kaser insisted that the modular system grew out of the modernist design philosophy of "Form follows function." He could see no function in the large, separate reading rooms and in the cramped, closedstack arrangements that had dominated library design previously. But by doing so, he ignored the practical, functional aspects of such layouts. Prior to the 1950s, few libraries "enjoyed" effective airhandling systems. Artificial lighting was weak, offering more heat than luminance. It made sense to segregate users from books. High ceilings and large windows created naturally quiet, cool, and well-lit spaces for users. Books did not need such an environment, and it was more efficient to grant them no more space than they needed. Metcalf admitted that "In many ways the contemporary undergraduate may be worse off than his predecessors; the great monumental reading rooms of earlier days absorbed noise and tended to engulf the reader just as a large stadium filled with a cheering crowd may leave the athlete oblivious of everything but his immediate surroundings." 7 Yet his discussion of ceiling height reads more like a contest to see how low ceilings

\section{ILLUSTRATION 3}

Daylighting and compact shelving in a new LEED-gold library: The Wise Law Library, University of Colorado at Boulder. What would otherwise be an unwelcoming basement is sunny and comfortable.

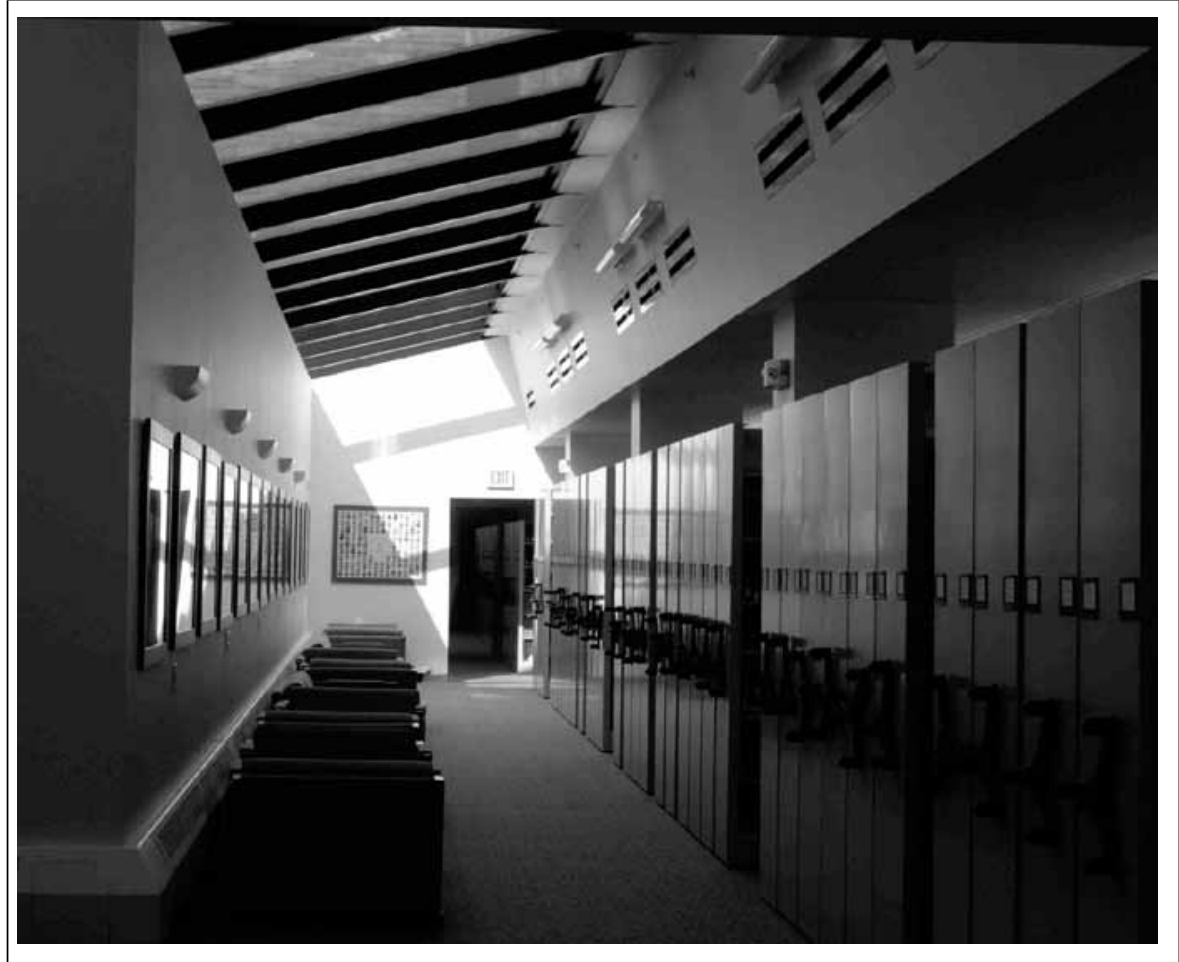


could be placed before users would admit to discomfort.

The modular system may have appealed to some librarians due to its flexibility, efficiency, and accessibility, but it had another appeal: modular buildings were cheaper to build. In an era in which up-front construction costs were the only costs worthy of serious consideration, and the energy costs for heating and cooling could largely be ignored, this was a critical factor. This usually meant minimal fenestration (or all-glass walls, permanently sealed), low ceilings, clustered seating with little or no privacy, and forced-air HVAC systems that created steady, year-around climates. The perfect housing for books, perhaps, but not for people. It did not matter. The students and the faculty had to come anyway, because the library was the only research game on campus. All the techniques that architects had previously used to create comfortable user spaces could be ignored. Getting the most accessible square footage for books became more important.

Until the 1950s, architects had to design comfort into the structure of a building itself. Few libraries had air conditioning or forced-air ventilation systems. If a library was to be comfortable for users, that comfort had to come from the way the spaces acted. That is why reading rooms had high ceilings and large windows to reduce lighting needs, and why books ended up in closed stacks unused by all but staff.

The new experts decried the "wasted" space in these reading rooms and hallways because air-handling systems could keep fresh, conditioned air available even in rooms with minimal ceilings. They often denigrated large windows because natural light caused books to deteriorate. Massive use of fluorescent lights raised foot candles to levels equal to or brighter than the old natural light levels. It did not matter. People have always acted as if the cost of electrical power was not important. The lifetime costs of libraries were not serious considerations.
But there was an additional factor, and that lies at the heart of where library buildings were headed until the turn of the last century. Metcalf states as inalterable: "Behind the whole problem of planning library buildings is a generally recognized fact, which is so important that it bears repeating and emphasizing. Libraries and those responsible for them have never found a satisfactory way of preventing or even slowing up the growth of library space requirements." 8 By this he meant shelf space, not user space, or, as Scott Bennett, promoter of libraries for learning, has pointed out, "Book space, not reader space, came to dominate ... over a period of fifty years." ${ }^{\prime \prime}$ Academic libraries will always need more space for books; libraries need to be able to expand collections. Students need books - lots of them; the more a library has, the better it will be able to serve its users. Or so the story went.

Times have changed, and what Kaser, Metcalf, and Ellsworth accepted as purest truth has come face-to-face with the brutal reality of computerized knowledge, new models of scholarly communication, and an end to the era of cheap energy. All three of these factors have changed what libraries are and what the designs of their homes need to be.

Premier institutions once made a point of owning nearly every publication, routinely ordering all new works from many publishers. The number of volumes a library owned was a major part of an institution's bragging rights, a figure pushed on potential students and other schools at every opportunity. These ever-expanding collections did require ever-expanding buildings. But escalating costs and the decrease in the number of private, academic publishers to a few nearly monopolistic, high-priced firms "have forced libraries to adopt new philosophies of access to information rather than strive for self-sufficiency through ownership of information." ${ }^{10}$ In the contest of access versus ownership, access has won. 
In addition to once buying everything, academic libraries used to retain everything as well, including works in obsolete formats. As David Kapp argued, "[in research libraries] newer information technologies are unlikely to replace more traditional ones." ${ }^{11}$ Yet the rapid turnover in digital formats now sees libraries converting holdings to new formats and discarding old technologies and their records at a dizzying rate. Even that most honored of formats: the codex, is disappearing from the shelves in reference, as are indexes and bound periodicals. All are becoming increasingly online standards. This author remembers when annual subscriptions to basic research sources such as Biological Abstracts, Chemical Abstracts, and Psychological Abstracts each ate up yards of shelves every year. The online versions cost money, but they are easier to search and they take no shelf space.

What green libraries have accepted is that "perpetual growth is an unsustainable fantasy." ${ }^{12}$ Housing miles of little- or never-used tomes in huge, climatecontrolled buildings is not efficient use of resources. Limiting physical size and growth is as much or a greater commitment to a lower-energy use future as any of the various LEED-inspired gestures such as motion-activated lights and genuine linoleum floors pointed out on tours.

The second change lies in the shift away from collection development and toward enhancing the patron experience. We have had no choice. Books do not use the library-people do-and libraries now have competition. The knowledge accessible via the World Wide Web and other online resources continues to grow, as does its quality, accessibility, and convenience. Learning the subtle details of a classification system and wending one's way through miles of stacks in search of a book that may or may not be where it is supposed to be, and may or may not answer the question, increasingly seems a waste of time. Besides, who has time to read an entire book? As for the sacred refereed journal, once so carefully sub- scribed to, collected, and bound? Online accessibility has largely taken that expensive shelf-filler away.

If access to the world's knowledge is everywhere, why would a user come to the library? The answer can be seen in the major shifts in programming everywhere. Libraries are offering more user comforts and librarians are teaching more, trying to emphasize the value-added, expert services that only a librarian can provide. And the buildings themselves are changing. Crammed study carrels set along windowless walls and tables hidden in stacks do not cut it. Users want and are getting open areas, natural light, and space to spread out their materials and personal gadgets. This was apparent in all the libraries the author visited. Here is a happy meeting of user desires and green criteria. Modules and stack systems went readily together and user desires could be largely ignored when the library was the only game in town. This is no longer true.

\section{Energy and Spaces}

The surveys that Harold B. Shill and Shawn Tonner conducted in 2001-2002 ${ }^{13}$ touched on many of the major shifts in academic library building design that had been occurring over a seven-year period. Their study focused on new construction and renovation in the period 1995-2002 and showed increases in square footage in almost all instances. But, even a decade ago, user space priority and an expanded use of compact shelving indicated the direction that libraries would be heading. Other changes Shill and Tonner documented included a greater sharing of facilities with other tenants, more wiring, and more food services. Personal observations reinforced some of their findings and gave more detailed evidence of what have become permanent changes in the functions academic libraries serve, and how their spaces are used to reach these newer goals. However, Shill's particular interest in the role and expansion of electronics did not appear to still be an issue. (Wireless is now a standard 
everywhere.) Nor-with the exception of the 1950 Hayden Memorial Library at MIT - is collection expansion space. This is due to the shift already noted to zero or minimal collections growth. But what is now an issue, and Shill and Tonner barely touched on, are the other major changes occurring that relate to energy.

Looking back, the period from 1950 through 1972 can be seen as a blip on the overall trend of energy costs and consumption. It was easy to disregard heating and cooling costs because energy was so underpriced during that period. Forced-air HVAC systems-inefficient, wasteful, and requiring extensive maintenance-were seen as the solution for all interior environmental challenges.
Constant year-around temperatures were the norm. Fluorescent lights solved the heating problems of incandescent bulbs and reduced the need for fenestration. Windows did not need to be capable of being opened because that could only compromise both the climate controls and collection security. So where did that leave the user? And where did that take the energy bills when the true lifetime costs of maintaining fixed temperatures and light levels finally needed to be calculated? The new academic libraries being built since the turn of the century increasingly reflect all these energy issues, and collectioncentric modularity is losing out.

To give Metcalf his due, he actually found the ever-increasing light levels be-

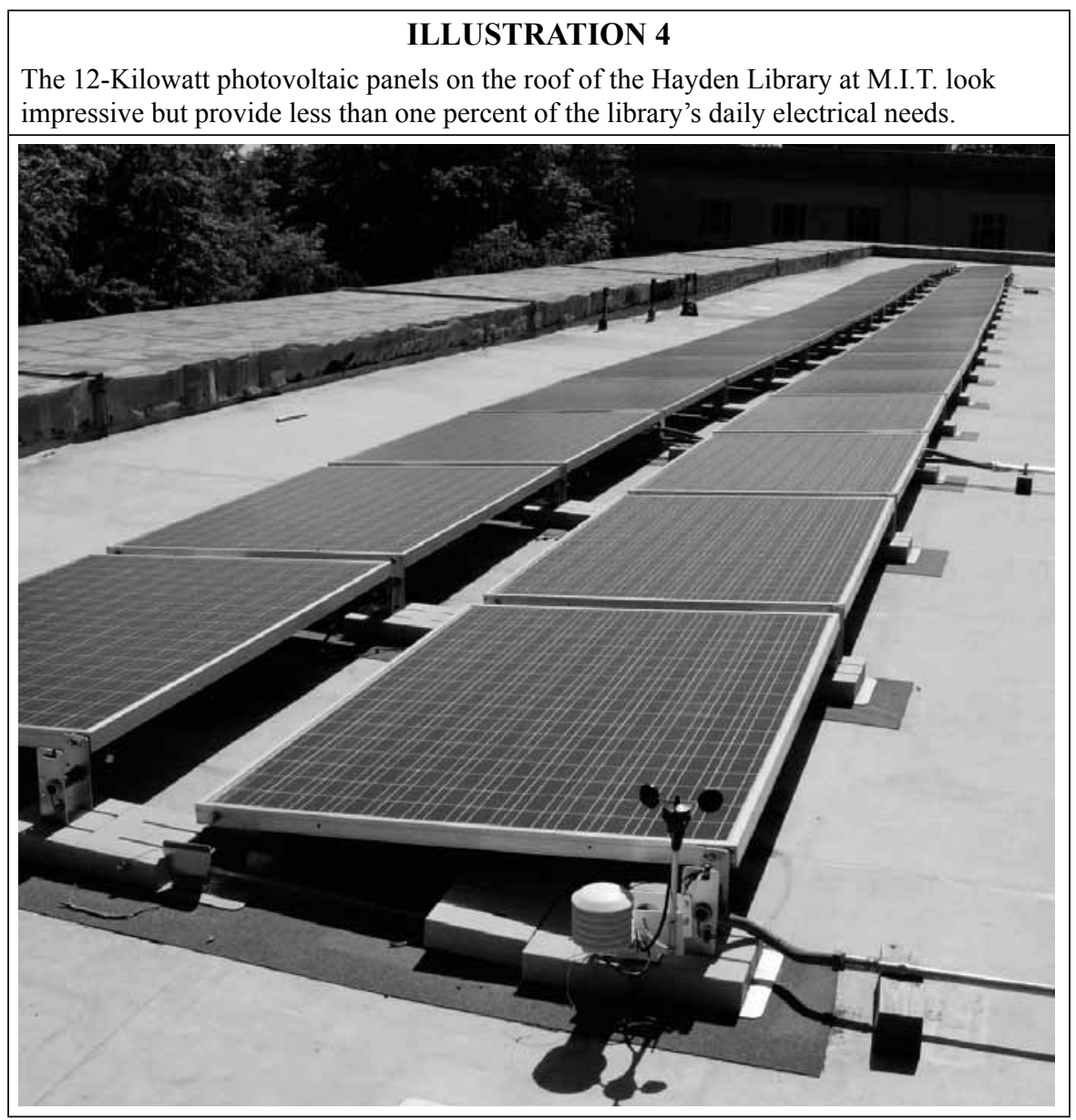




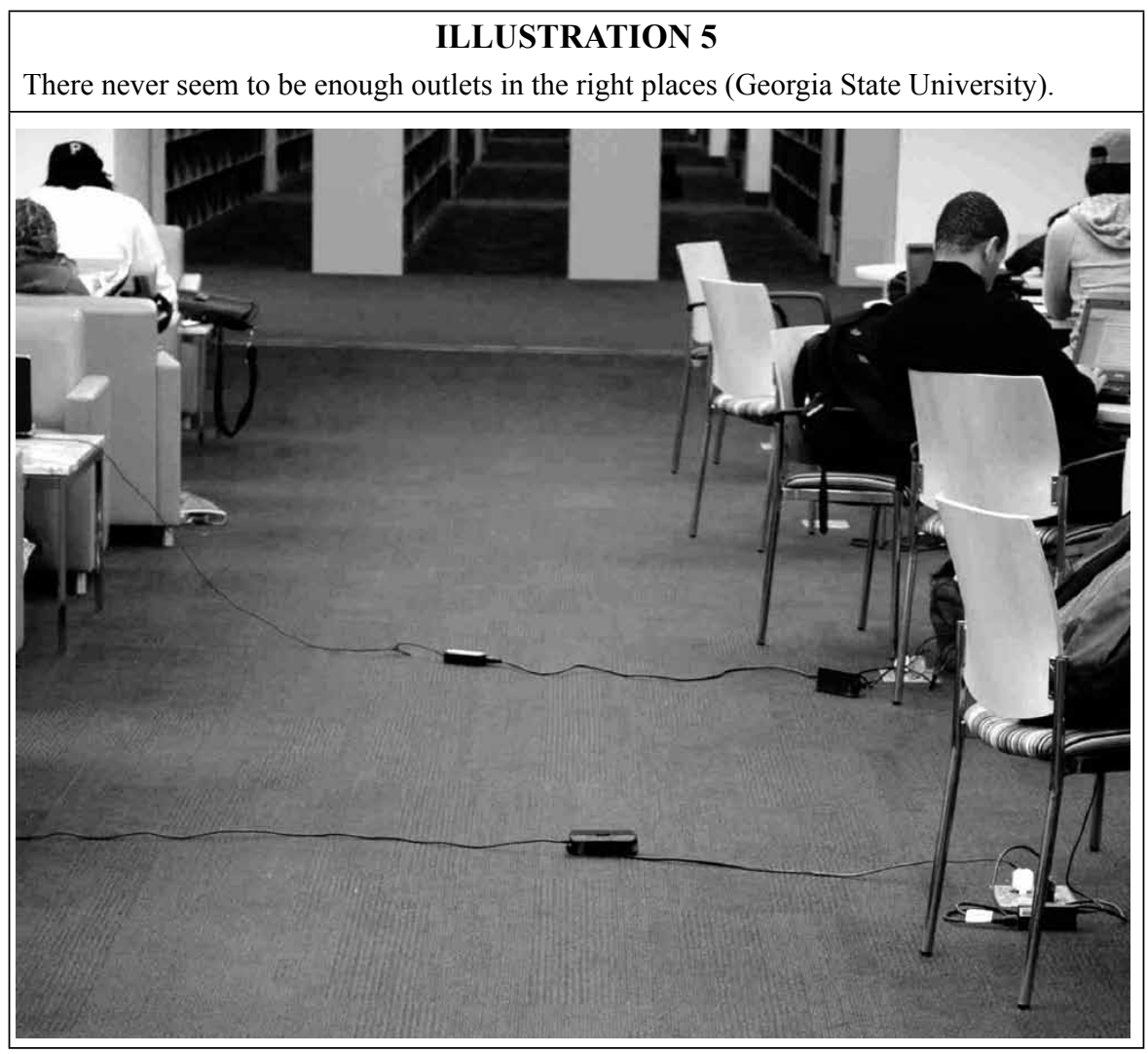

ing placed in newer libraries during most of the 20th century somewhat mysterious. He admitted that he did not understand how once " 3 or 4 foot candles were considered adequate" ${ }^{14}$ when, by the 1960s, standards called for ranges of 12 to 25 foot candles. But it seems like everyone in this country has always acted as if electricity is free. Lights, computers, and printers are always on. The personnel I spoke with at MIT admitted that the Institute's electrical bill was running at more than a million dollars a week! Their photovoltaic demonstration project on the roof of the Hayden Library was generating a respectful 12 kilowatts of power, but it met less than one percent of the library's daily electrical needs. This is the kind of expense level that colleges and universities - and particularly older libraries-are now facing, and the one space-fits-all-needs philosophy of the modular library is losing out.
So where is a sustainable future taking these libraries? Some thoughts:

As already noted above, new academic libraries are increasingly reflective of the recognition of the limits to growth-the very essence of "green." All the libraries visited have a specific collection size in mind and do not intend to exceed that limit. Reference collections are already shrinking. The continuous binding of periodical collections is largely a practice of the past. Even microform collections are disappearing as more and more periodicals are accessible electronically. Book collections are still growing, but more slowly; and older, unused tomes are being sent offsite or even being eliminated if they are not being used. Institutions are recognizing that they can no longer afford the space and energy to support infinitely expanding collections. Nor are such collections necessary. The universal acceptance of interlibrary 
loan, the development of speedy delivery mechanisms, and large-scale scanning of text into electronic formats have removed the need for every possible book to be on site to be useful. "Just in case" is no longer enough justification for the purchase of marginal works that, once shelved, may never see a single turn of a page.

As spaces for collections have declined in importance, spaces for users have become paramount. This means more human-friendly rooms, plenty of table or carrel space, studies with windows, food and drink cafés or vending machines, extended hours, and games to entertain. Spacious, user-friendly reading rooms with high ceilings were once seen as space wasters. Often, added floors or dropped ceilings granted more space for books and pushed users out of these rooms in the process. Now libraries are tearing out those added floors and reopening the spaces to serve users. ${ }^{15}$ Study rooms are as close to antimodular as one can get, yet that is what users want and what they use wherever available. All of the visited libraries had student study rooms, and they were seeing heavy usage. Wireless is reducing the need for hard-wired Internet connections - but not a single visited library seemed to have enough power receptacles in the right places.

In the process of adding user spaces, staff needs and space layouts have changed. Technical services, once front and center and critical for in-house cataloging and the maintenance of the cards in the card catalogs, have largely moved into nonprime spaces or offsite.

In the greening of these libraries, the lifetime costs of a building have become as important as the initial construction costs. There is an open recognition that heating and cooling now cost real money and more and more of it. Patrons prefer natural lighting, and it saves energy costs. Spaces designed to vent themselves give savings as well. Increased insulation, building for sun orientation, and more careful attention to space usage have little or nothing to do with modularity but point to the critical future.

\section{ILLUSTRATION 6}

The restored reading room in Atlanta, Georgia's Emory University, is once more bathed in natural light, the result of a LEED-silver renovation.

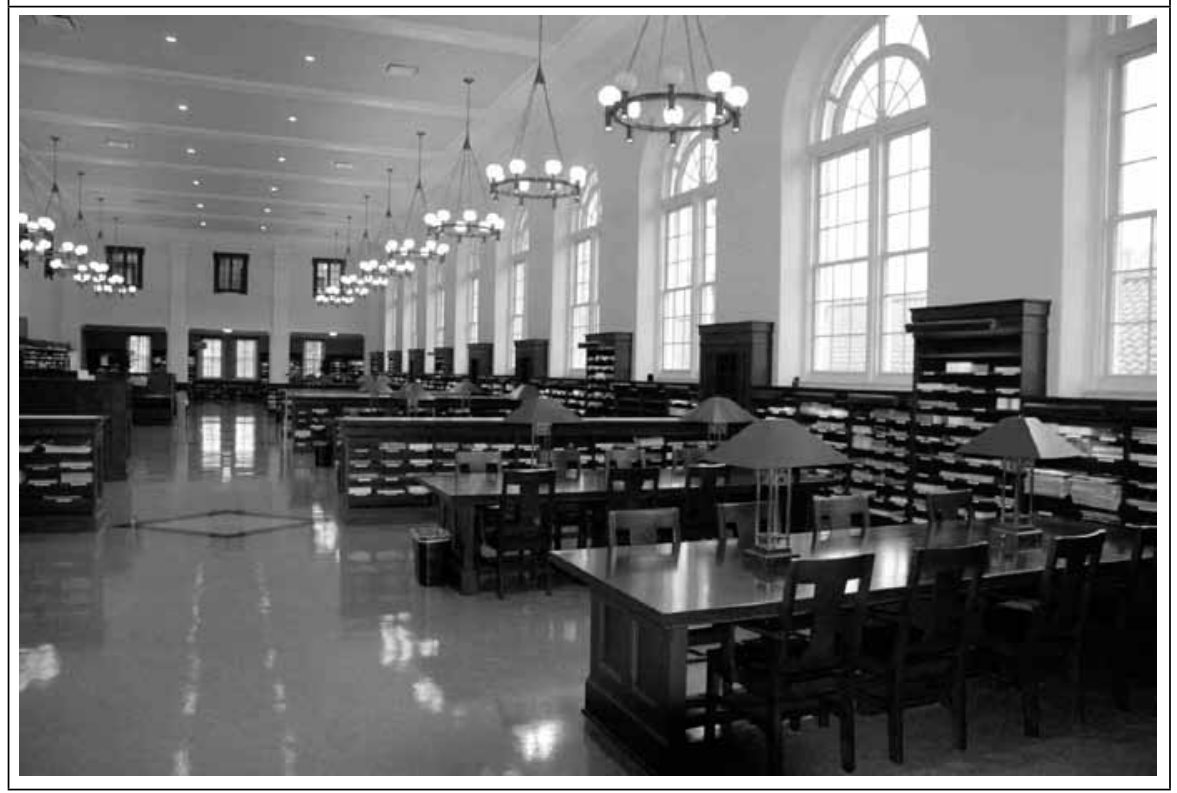




\section{Conclusion}

What Metcalf and Kaser championed is what Stewart Brand, in his fine study of architectural change, How Buildings Learn, ${ }^{16}$ refers to as "low road" buildings. Warehouses, many factories, and other utility buildings offer inherent flexibility with their open spaces and minimal interior walls. Equal-sized bays and modularity in such buildings allow inexpensive changes in function. But libraries, by their very nature, are not low road, but rather "high road" buildings, filled with symbolism and the focus of a community's hopes and aspirations. Such buildings need to present at least the illusion of permanence and offer a style and graciousness that welcomes all users. Books might love a modular setting; but, when people become more important than books, modularity is the loser. A confirmation of this clearly shows in a class project reported by Michelle Twait. ${ }^{17}$ Asked to design a renovated library and its spaces, her students' plans called for more study spaces and study rooms, group areas, a café and themed reading rooms-all specialized spaces that have become of first importance in the libraries the author visited. But more striking was that they wanted this library also to have a grand entrance "to show those who pass by that this is a place to further your learning ..."18 Perhaps this is a postmodernist reaction to the dull, raw-concrete minimalist structures of the middle decades of the last century, but it also can be seen as part of a green philosophy where the buildings work through their design and not just through their systems.

Kaser decried the many libraries being built with features that simply drew attention to the "high road" status of a library. He condemned monumentality, excessive glass, and other fads. We cannot argue with any of these criticisms, but the nearly windowless boxes oriented toward endless collection growth and warehousing are no longer the future. What is needed is acceptance of a new basis of academic and research library design that speaks to the needs of users, is energy efficient, and assumes zero-growth of physical collections. Such a building will have a future on any campus.

\section{Notes}

1. LEED is a certification program that rates the design, construction, and operation of green buildings. The U.S. Green Building Council, a nonprofit based in Washington, D.C., coordinates the program. See www.usgbc.org/Default.aspx.

2. David Kaser, "Twenty-five years of Academic Library Building Planning," College E Research Libraries 45 (July 1984): 268-81.

3. David Kaser, The Evolution of the American Academic Library Building (Lanham, Md.: Scarecrow, 1997).

4. Keyes D. Metcalf, Planning Academic and Research Library Buildings (New York: McGraw Hill, 1965).

5. An examination of December (Architecture) issues of Library Journal over the last twenty years reveals that hardly a year has gone by without Shepley, Bulfinch, Richardson \& Abbott (SBR\&A) on the list of architectual firms for major academic library building projects. In addition, Geoffrey Freeman. Principal at SBR\&A, has been a frequent speaker at library events and contributed to books on the design of academic library buildings. For examples, see: Geoffrey Freeman, "The Academic Library in the 21st Century: Partner in Education" in: Building Libraries for the 21st Century: The Shape of Information, ed. T.D. Webb (Jefferson, N.C.: McFarland, 2000), 168-75; and Library as Place: Rethinking Roles, Rethinking Space, CLIR Pub. no. 29 (Washington, D.C.: Council on Library and Information Sources, 2005), 1-9.

6. Harold B. Shill and Shawn Tonner, "Creating a Better Place: Physical Improvements in Academic Libraries, 1995-2002," College E Research Libraries 64 (Nov. 2003): 431-66; Shill and Tonner, "Does the Building Still Matter? Usage Patterns in New, Expanded, and Renovated Libraries, 1995-2002," College \& Research Libraries 65 (Mar. 2004): 123-50.

7. Metcalf, Planning Academic and Research Library Buildings, 4.

8. Metcalf, Planning Academic and Research Library Buildings, 3. 
9. Scott Bennett, "Libraries and Learning: A History of Paradigm Change," Portal: Libraries and the Academy 9, no. 2 (Apr. 2009): 185.

10. Janet Fore, R. Cecilia Knight, and Carrie Russell, "Leadership for User Services in the Academic Library," Journal of Academic Administration 19 (1993): 98.

11. David Kapp, "Designing Academic Libraries: Balancing Constancy and Change" in "Forgiving Building: A Library Building Consultants' Symposium on the Design, Construction and Remodeling of Libraries to Support a High-Tech Future," Library Hi Tech, 20 (1987): 82

12. Henry Pisciotta, e-mail subject line, "Library Building Design," April 24, 2009 to Michael Wescott Loder

13. Shill and Tonner, "Creating a Better Place."

14. Metcalf, Planning Academic and Research Library Buildings, 182.

15. Examples of this retro-renovation include: The restored reading room in the Candler Library at Emory University, the reading rooms in the renovated Thompson Library at Ohio State University, and the restored Special Collections room in Lehigh University's Linderman Library. See Joseph J. Branin, "Shaping Our Space: Envisioning the New Research Library," Journal of Library Administration 46 (2007): 49-51. 1994)

16. Stewart Brand, How Buildings Learn: What Happens After They're Built (New York: Viking,

17. Michelle Twait, "If They Build It, They Will Come: A Student-designed Library," College $\mathcal{E}$ Research Libraries News 70 (Jan. 2009): 21-23.

18. Twait, "If They Build It, They Will Come," 24.

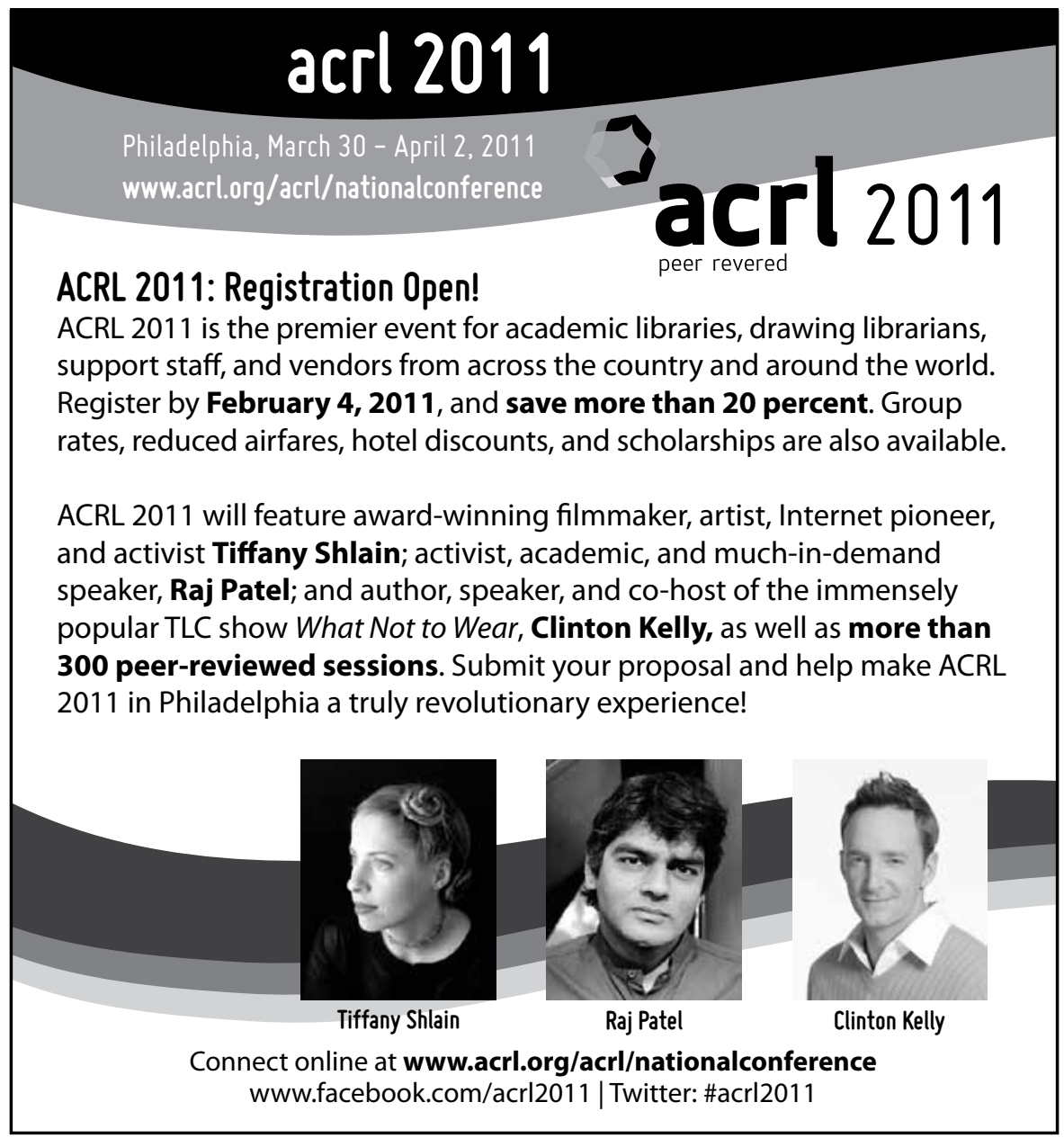

